Ks. Franciszek DRĄCZKOWSKI

(Lublin, KUL)

\title{
POWSZECHNOŚĆ FUNKCJI KERYKSA W KOSCIELE STAROŻYTNYM. STANOWISKO KLEMENSA ALEKSANDRYJSKIEGO
}

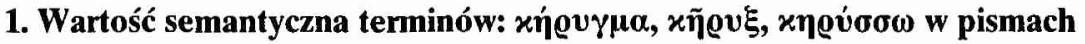
Klemensa Aleksandryjskiego. Wyżej wymienione dwa rzeczowniki oraz czasownik, w swym pierwotnym znaczeniu, wiązały się głównie z przekazem ustnym, w którym niezastąpioną rolę odgrywał głos ludzki. Daje się to szczególnie

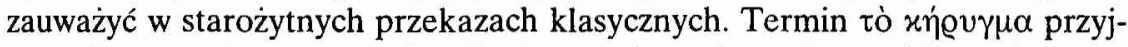
mował następujące znaczenia: obwieszczenie, ogłoszenie, proklamacja, ogłaszanie przez herolda, kazanie ${ }^{1}$. Rzeczownik ó $x \bar{\eta} \varrho v \xi$ - oznaczał: herolda, publicznego posłańca, licytatora, obwoływacza, zwiastuna, głosiciela ${ }^{2}$. Czasownik khrssw przyjmował głównie następujące znaczenia: być heroldem, spełniać urząd herolda, być licytatorem, ogłaszać, podawać do wiadomości, głosić kazanie, nauczać publicznie ${ }^{3}$.

W pismach Klemensa, jak i w ogóle w piśmiennictwie wczesnochrześcijańskim $^{4}$, zakres znaczeniowy poszczególnych terminów uległ daleko idącemu poszerzeniu, co daje się szczególnie zauważyć na przykładzie terminu tò

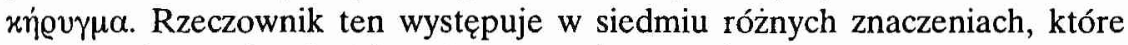
można uplasować w dwóch podstawowych grupach:

I. Termin $\tau$ ò $x \eta ́ \varrho v \gamma \mu \alpha$ oznacza czynność dokonywaną w czasie:

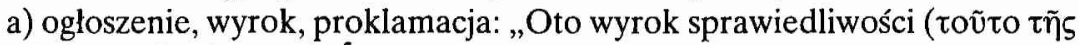

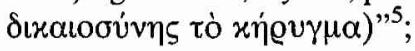

b) gloszenie kazania, gloszenie Ewangelii: „Wobec tego, że sprawy tak się mają, prorocy uzyskują doskonałość w proroctwach, sprawiedliwi w sprawied-

${ }^{1}$ Por. Stownik grecko-polski, red. Z. Abramowiczówna, II, Warszawa 1960, 659 (dalej cyt.: Abramowiczówna); G.W.H. Lampe, A Patristic Greek Lexicon, Oxford 1961, 751-752 (dalej cyt.: Lampe).

${ }^{2}$ Por. Abramowiczówna s. 659; Lampe s. 752

${ }^{3}$ Por. Abramowiczówna s. 659; Lampe s. 752.

${ }^{4}$ Por. F. Drączkowski, Kerygmat pisemny w teorii i praktyce Klemensa Aleksandryjskiego, RTK 26 (1979) z. 6, 24-26.

${ }^{5}$ Protrepticus 116, 1, thum. J. Solowianiuk, PSP 44, 197, thum. franc. C. Mondésert, SCh 2, 184: „Telle est la proclamation de la justice". 


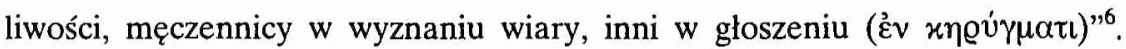
Dotyczy to czynności głoszenia Dobrej Nowiny realizowanej przez Jezusa Chrystusa, Jego apostołów i ich następców;

c) aplauz, oklaski, brawa, radosne okrzyki. W tym znaczeniu termin tò $x \eta \dot{\varrho} v \gamma \mu \alpha$ Klemens Aleksandryjski stosuje, gdy porównując za św. Pawłem życie ziemskie do zawodów sportowych pisze, że doskonały chrześcijanin winien tak postępować, by „uznany jawnie za godnego niebieskiej ojczyzny, wszedł do niej uwieńczony pośród triumfalnych okrzyków anielskich ( $\mu \varepsilon \tau \dot{\alpha}$

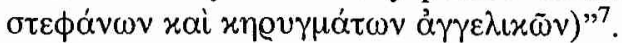

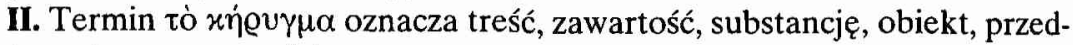
miot, w pierwszym rzędzie:

a) materię, treść wszelkiego przepowiadania, doktrynę. Klemens Alek-

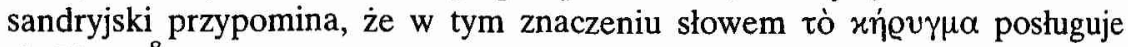
się Platon ${ }^{8}$.

b) treść apostolskiego przekazu, Ewangelię, zawartą w nauczaniu Jezusa Chrystusa i Kościoła. To znaczenie najbardziej rozpowszechnione jest w pismach patrystycznych, zarówno w dzielach Klemensa Aleksandryjskiego", jak równiez innych autorów ${ }^{10}$.

c) apostolską tradycję wiary. Znaczenie to występuje nie tylko u Klemen$\mathrm{sa}^{11}$, lecz również u innych starożytnych pisarzy chrześcijańskich ${ }^{12}$.

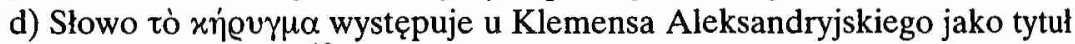

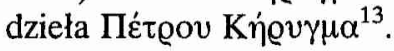

${ }^{6}$ Stromata IV 133, 1, GCS 52, 307, tłum. J. Niemirska-Pliszczyńska: Kobierce zapisków

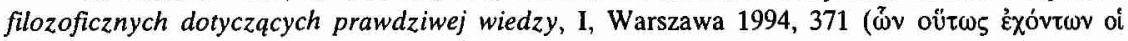

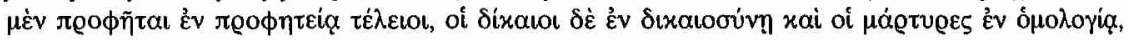

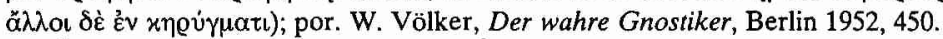

${ }^{7}$ Quis dives salvetur 3, 6, GCS $17^{2}, 162$, tłum. J. Czuj: Który czlowiek bogaty może być

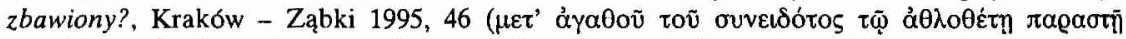

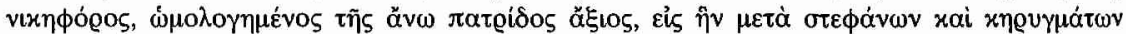

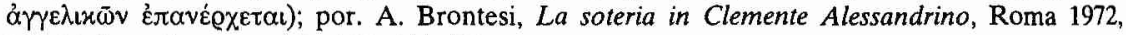
358; Völker, dz. cyt., s. 161, 163, 464, 498.

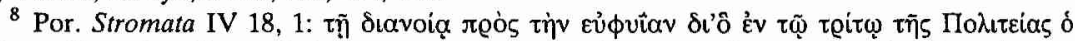

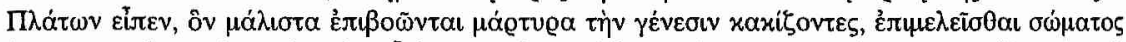

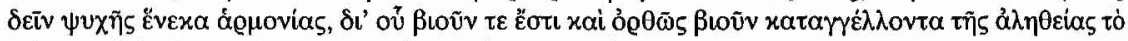

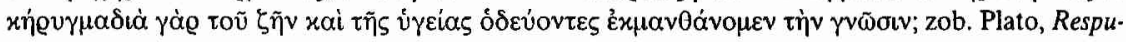
blica III $410 \mathrm{C}$.

${ }^{9}$ Por. Stromata VI 44, 1; 48, 3; zob. Brontesi, dz. cyt., s. 28, 41-42, 532; Völker, dz. cyt., s. 145.

10 Por. Hermas, Pastor, similitudo VIII 3, 2; Gregorius Nyssenus, Oratio catechetica 13, PG 45 , 45B; Hippolytus Romanus, Refutatio omnium haeresium sive philosophumena 5, 8, PG 16, 3143A; Origenes, Commentarii in Joannem 5, 8, PG 14, 196B; Epiphanius, Panarion 73, 6, PG 42, 413A.

11 Por. Stromata II 38, 1; Protrepticus 99, 4; zob. Brontesi, dz. cyt., s. 4, 21, 23-24, 26, 52, 467, 522.

12 Por. Irenaeus, Adversus haereses I 10, 2, PG 7, 552 A; Origenes, De principiis III 1, 1, PG 11, 249A; Eusebius, HE III 32, 7, PG 20, 284C; Gregorius Nyssenus, Contra Eunomium X, PG 45, 832D.

${ }^{13}$ Por. Stromata II 68,$2 ;$ VI 39,$1 ; 42,3 ; 48,1 ; 128,1$. 


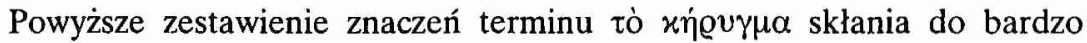
ważnej konkluzji, tej mianowicie, że kerygmat oznacza nie tylko czynność przepowiadania, ale przede wszystkim treść przekazu, który może dokonywać się $\mathrm{w}$ formie ustnej bądź pisemnej. $\mathrm{Z}$ tej też racji należy mówić nie tyle o głoszeniu Słowa Bożego, ile o jego propagowaniu. Nośnikiem treści Dobrej Nowiny jest słowo, które może być powiedziane lub zapisane.

$\mathrm{Z}$ tej też racji Klemens $\mathrm{z}$ naciskiem akcentuje równorzędną wartość obu kerygmatów: pisemnego i ustnego. Przy różnych okazjach, kiedy przedmiotem wykładu jest przekaz prawdy, Klemens akcentuje tę dwojaką możliwość. Nawiązując np. do wypowiedzi Klemensa Rzymskiego przypomina:

„Szlachetne i nieskazitelne postępowanie, wyrosłe z naszej miłości do człowieka, szuka, według Klemensa ${ }^{14}$, wspólnego dobra, czy to jeśli dajemy świadectwo (żáv $\tau \varepsilon \mu \alpha \varrho \tau v \varrho n ̃)$, czy wychowujemy czynem i słowem (

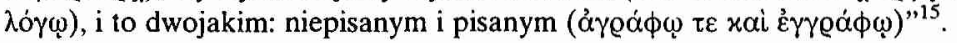

Podobnie też wszelkie nauczanie, które w ujęciu Klemensa Aleksandryjskiego, jest działaniem na rzecz dobra bliźniego i jako takie zaliczane jest do dobrych uczynków o najwyższej wartości ${ }^{16}$, może być realizowane ustnie lub

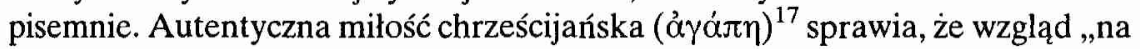
pożytek bliźnich skłania jednych do działalności piśmienniczej, innych znowu kieruje na drogę przekazywania nauki ustnie"18.

W innym miejscu - czyniąc aluzję do ewangelicznych przypowieści o siewcy i żniwiarzach, w których trud rolnika uprawiającego ziemię przyrównywany jest do pracy krzewiciela słowa Bożego - pisze:

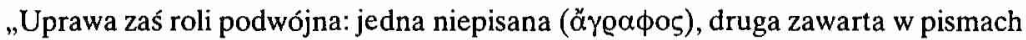

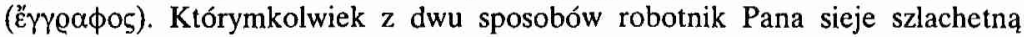
pszenicę, czuwa nad wzrostem klosów oraz dopełnia żniwa - prawdziwie boskim okaże się rolnikiem"19.

${ }^{14}$ Por. Clemens Romanus, Epistola ad Corinthios 48, 1, 6.

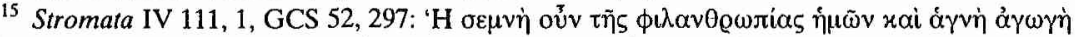

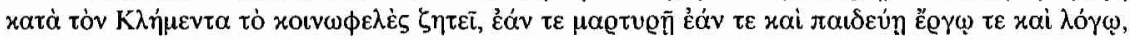

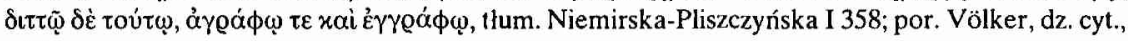
s. 296.

${ }^{16}$ Por. Stromata VI 91, 5; I 4, 1; zob. Brontesi, dz. cyt., s. 6, 463; Völker, dz. cyt., s. 95, 119, 337 , 556.

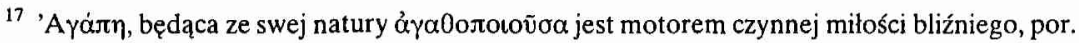
Stromata IV 113, 4; 1J 4, 8. 16.

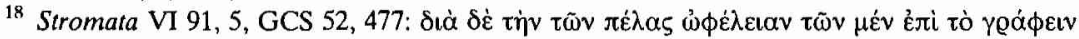

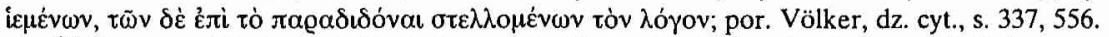

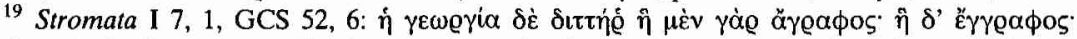

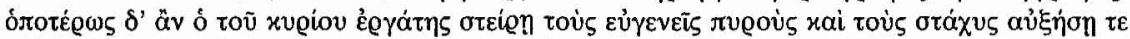

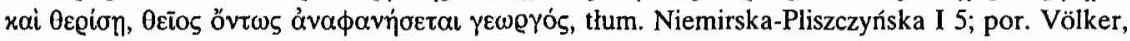
dz. cyt., s. 5. 
W powyższej wypowiedzi zostala zaakcentowana równorzędność obu kerygmatów co do zasługi. Wydaje się to Klemensowi rzeczą naturalną i oczywistą, że praca włożona $w$ apostolat pisemny powinna być na równi doceniona $z$ trudem związanym $z$ apostolatem ustnym. Dlatego, z pewnym jakby zniecierpliwieniem dodaje:

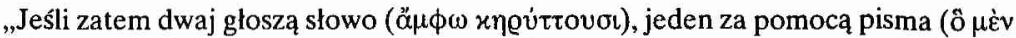

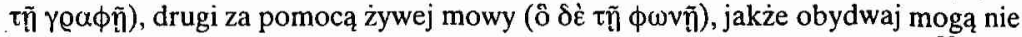
zaslugiwać na pochwałę, wprowadziwszy swą wiarę w czyn przez milość?"2n.

Na uwagę zasluguje fakt odniesienia czasownika khrssw zarówno do przekazu

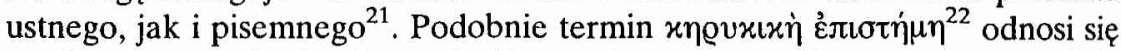
w równym stopniu do obu rodzajów przekazu ewangelicznego: ustnego i pisemnego, przy czym żadnej $\mathrm{z}$ tych form nasz autor nie preferuje, kiedy pisze:

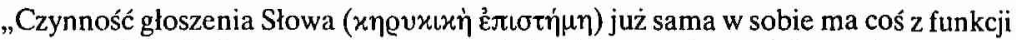
apostolskiej w każdym z tych dwu sposobów skutecznej: czy dokona się ręką czy, językiem"23.

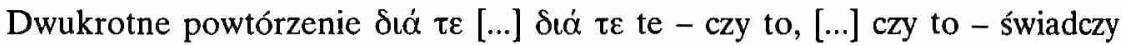
właśnie o tej równorzędności. Wydaje się, że w zamierzeniu Klemensa traktowanie na równych prawach apostolatu ustnego i pisemnego miało stanowić wzmocnienie misyjnego nakazu Chrystusa, gdyż każdy - w miarę swych możliwości - mógł wybrać sobie właściwą formę apostołowania.

Konsekwentnie do tego założenia miano keryksa przysługuje nie tylko temu, kto propaguje słowo Boże przez przekaz ustny, ale również temu, kto ewangelizuje poprzez pisma, czyli kerygmat pisemny. Warto zwrócić uwagę na fakt, że „kerygmat pisemny” nie jest uzależniony od oficjalnej delegacji Kościoła, czyli nie jest związany ze stopniem w hierarchii kościelnej. W czasach Klemensa istniały trzy stopnie hierarchiczne ${ }^{24}$ : biskupów, prezbiterów i diakonów. Klemens wspomina o tym wyraźnie w slowach:

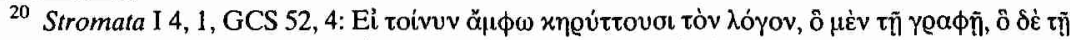

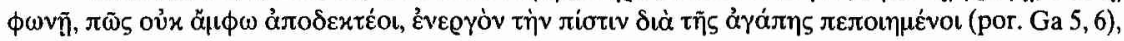
tłum. Niemirska-Pliszczyńska I 3; zob. Brontesi, dz. cyt., s. 6, 463; Völker, dz. cyt., s. 95, 119.

${ }^{21}$ Dlatego też tłumaczenie powyższego tekstu powinno raczej brzmieć: „Jeśli zatem dwaj krzewią słowo" (lub: przekazują, propagują, rozpowszechniają), ponieważ „głosić słowo" można przy pomocy „głosu”, a nie przy pomocy „pisma”.

22 Por. Stromata I $4,2$.

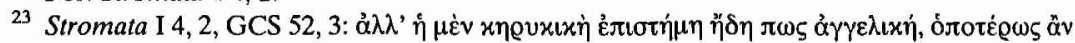

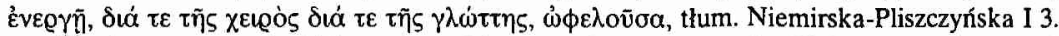

${ }^{24} \mathrm{Na}$ temat urzędu biskupa i prezbitera u Klemensa por. A. Vilela, La condicion collégiale des prêtres au III siècle, Paris 1971, 27-42; U. Neymeyr, Episkopoi bei Clemens von Alexandrien, StPatr 26 (1993) 292-295; tenże, Presbyteroi bei Clemens von Alexandrien, StPatr 31 (1997) 493496; P. Szczur, Urzqd biskupa w świetle pism Klemensa Aleksandryjskiego, w: Ku prawdzie w mitości. Księga pamiq̨tkowa poświęcona Księdzu Biskupowi Profesorowi Janowi Śrutwie, red. S. Koczwara, Lublin 2002, 63-69. 
„istniejące tu na ziemi w Kościele stopnie hierarchiczne: biskupów, prezbiterów, diakonów, są naśladownictwem, jak sądzę, wspaniałości anielskiej i owej ekonomii zbawienia, której mogą oczekiwać, wedle słów Pisma Świętego, ludzie, których życie upłynęło w pełni sprawiedliwości, zgodnie z. Ewangelią, wedle śladu stóp apostolskich" 25 .

$\mathrm{Z}$ jednej strony teoretycznie, każdy wierzący miał drogę otwartą do tworzenia kerygmatu pisemnego, z drugiej jednak strony autor nasz postuluje, by keryks słowa pisanego posiadał odpowiednie kwalifikacje, do których należy zaliczyć: czystość intencji apostołowania oraz właściwą formację intelektualnomoralną ${ }^{26}$.

2. Chrystocentryczny wymiar kerygmatu. Klemens Aleksandryjski na samym początku swego największego dzieła Stromaty stawia pytanie, czy warto zostawić po sobie spuściznę literacką ${ }^{27}$ Odpowiedź na to pytanie stała się punktem wyjścia dla całego wykładu o charakterze ogólnym, na temat obowiązku przekazywania wiedzy i nauki w ogóle, chrześcijańskiej zaś w szczególności. Aleksandryjczyk przypomina, że celem ostatecznym wszystkich ludzi jest

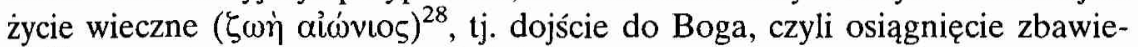
nia $^{29}$. W realizowaniu tego celu ludzie nie są sami, gdyż towarzyszy im Chrystus Wychowawca, Nauczyciel i Zbawca, który zbawia tych wszystkich, „którzy

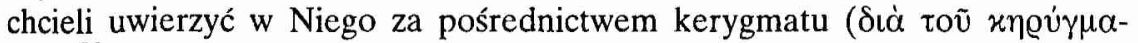
$\tau o \zeta) "$ "30. W ten sposób kerygmat prowadzi do wiary, ta zaś do zbawienia. Ponieważ wiara i zbawienie są powszechne, tj. przeznaczone dla wszystkich ludzi bez wyjątku, również powszechnym winien stać się kerygmat przeznaczo-

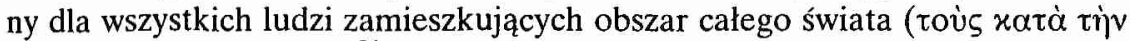

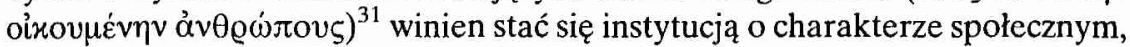

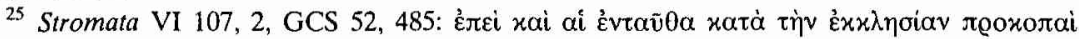

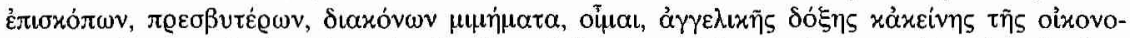

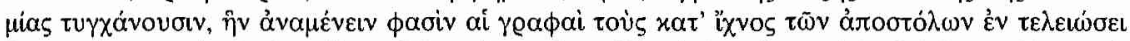

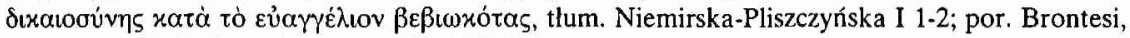
dz. cyt., s. 273; Völker, dz. cyt., s. 524, 586, 601.

${ }^{26}$ Por. Drączkowski, Kerygmat pisemny, s. 28-32.

${ }^{27}$ Por. Stromata I 1, 2, GCS 52, 3, Niemirska-Pliszczyńska I 1-2: „Za rzecz piękną uważam przekazanie przyszłości dorodnego potomstwa, a przecież to są dzieci tylko naszego ciała, duszy zaś potomstwem jest twórczość umyslu"; zob. Plato, Symposium 209A-D; Phaedrus 278A; Theaetetus 150D; Aristoteles, Ethica Nicomachea IX 7, 3-1168 1-3; Brontesi, dz. cyt., s. 6, 463.

${ }^{28}$ Por. Stromata II 134, 3; Rz 6, 22.

29 Por. Stromata II 99, 3; 126, 3; zob. Brontesi, dz. cyt, s. 45, 205.

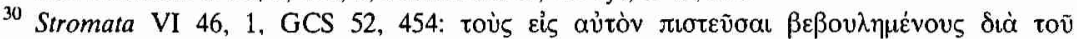

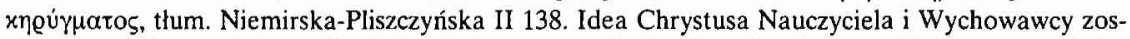
tała szczególnie rozwinięta w I księdze Pedagoga, por. E. Fascher, Der Logos - Christus als göttlicher Lehrer bei Clemens von Alexandrien, Studien zum Neuen Testament und zur Patristik (TU 77), Berlin 1961, 193-207; Brontesi, dz. cyt., s. 28, 38, 41-43, 56-57, 79, 136, 139, 141, 162, 202-203, 205-206, 308.

${ }^{31}$ Por. Stromata VI 48, 2; zob. Brontesi, dz. cyt., s. 141, 154, 203. 
która mobilizuje wszystkie środki zdolne do jego rozpowszechniania - w pierwszym rzędzie duże zespoły osób przekazujących. Klemens przypomina znamienne słowa Chrystusa o konieczności pracy misyjnej: „Żniwo wprawdzie wielkie, ale robotników mało" (Mt 9,37) - potem dodaje od siebie: „istotnie wypada pragnąć, żebyśmy mieli jak największą liczbę robotników"32.

$\mathrm{Z}$ drugiej strony, Klemens zdaje sobie sprawę nie tylko z powszechności kerygmatu, ale również $\mathrm{z}$ jego uniwersalnego przeznaczenia dla wszystkich pokoleń ludzkich, zarówno minionych jak i następnych. Wedhug Klemensa "Pan [Chrystus] zstąpił do Otchłani nie z żadnej innej przyczyny, jak tylko po to, aby i tam głosić Ewangelię"33; „Apostołowie zaś na wzór Pana głosili Ewangelię, również pozostających w Otchłani” ${ }^{34}$. Co więcej, uważa, że „Pismo [święte] daje wyraźnie do zrozumienia, że Pan głosił Ewangelię również tym, którzy zginęli w potopie" 35 . Ten historyczny uniwersalizm kerygmatu dotyczy nie tylko przeszłości i teraźniejszości, ale i przyszłości. Klemens cytuje słowa św. Pawla skierowane do Tymoteusza: „to, co usłyszałeś ode mnie w obecności wielu świadków, przekaż ludziom godnym zaufania, takim, którzy będa zdolni także nauczać innych"36. W tekście tym zawarty jest postulat ciągłości przekazywania nauki Chrystusa $\mathrm{z}$ pokolenia na pokolenie. Ta nieprzerwana kontynuacja jest drugą istotną cechą kerygmatu.

Chrystus według Klemensa jest jedynym Nauczycielem, jedynym źródłem Prawdy ${ }^{37}$. W swym wykładzie Klemens Aleksandryjski eksponuje ideę, że autorem Pisma świętego jest Boski Logos. Co więcej, Chrystus jako Nauczyciel jest obecny w Kościele poprzez Pismo święte. Klemens cytując autorów Starego Testamentu zaznacza, że to Logos „,mówi przez usta Izajasza”,38, ,przez Salomona”,39, „przez Jeremiasza”40 , „za pośrednictwem Dawida”41, „w Ewangelii Jana"42, ,w Ewangelii”,43.

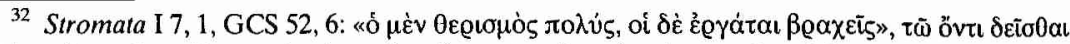

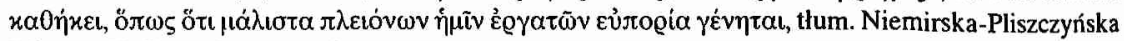
I 5; por. Völker, dz. cyt., s. 5.

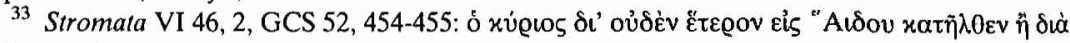

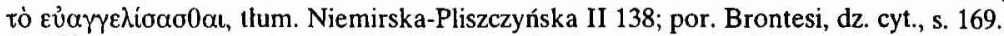

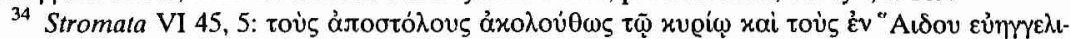

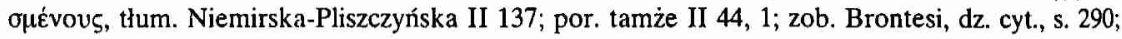
Völker, dz. cyt., s. 594.

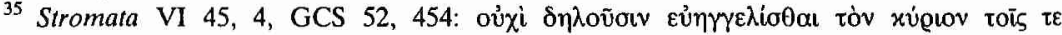

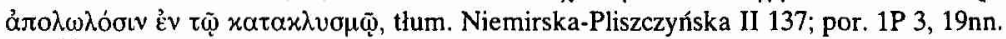

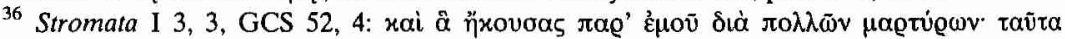

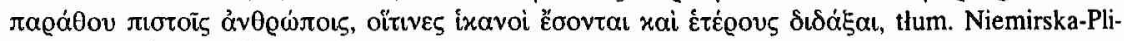
szczyńska I 3; por. 2Tm 2, 15.

37 Por. Stromata IV 54, 1; VI 62, 3; zob. Völker, dz. cyt., s. 350, 374.

38 Stromata VI 55, 2, GCS 52, 459; por. Völker, dz. cyt., s. 338.

${ }^{39}$ Paedagogus I 77, 3, thum. T. Puton, Pedagog - Księga I Klemensa Aleksandryjskiego. Wstęp - tlumaczenie - komentarz, Lublin 1977, mps BKUL; tamże I 78, 1. 
Dla Klemensa nie jest istotny fakt, że w Nowym Testamencie przemawia Logos Wcielony, Jezus Chrystus, a w Starym Testamencie mówi tenże Logos przez usta proroków i Dawida. Pismo święte traktuje jako jedną księgę, jednego autora. Jest nim Boski Logos, Nauczyciel. Chrystus Boski Logos, Odwieczna Mądrość, przemawiająca na kartach całego Pisma świętego, jest z natury rzeczy predysponowany na Nauczyciela wszystkich ludzi. Zdaniem Klemensa Chrystus jest nazywany Mądrością przez wszystkich proroków, jest Nauczycielem wszystkich bez wyjątku istot stworzonych, jest współdoradcą Boga wszystko naprzód wiedzącego ${ }^{44}$.

Boski Nauczyciel, Odwieczna Mądrość, jest pierwszorzędnym i głównym podmiotem kerygmatu. On to obwieszczal Dobrą Nowinę podczas swego ziemskiego pielgrzymowania; kontynuował swoją misję po śmierci krzyżowej, kiedy wstąpił do Otchłani, głosząc tam kerygmat wszystkim sprawiedliwym, którzy narodzili się przed Jego Wcieleniem ${ }^{45}$. Dobrą Nowinę o zbawieniu przepowiadał również tym, którzy zginęli w potopie ${ }^{46}$.

Kerygmat Dobrej Nowiny gloszonej przez Jezusa Chrystusa posiada walor uniwersalny, czyli powszechny, zarówno w wymiarze geograficznym jak i historycznym. Kerygmat jest ogniwem w dziele zbawienia, które winno stać się udziałem wszystkich ludzi bez wyjątku. Misja kerygmatyczna Jezusa Chrystusa staje się wieczna i ponadczasowa poprzez działalność apostołów i ich następców.

3. Apostołowie sługami kerygmatu Jezusa Chrystusa. Klemens Aleksandryjski w swych pismach akcentuje jedyność kerygmatu Jezusa Chrystusa, który realizuje się w Jego imieniu przez posługę apostołów. W II księdze Pedagoga interpretując alegorycznie scenę namaszczenia stóp Jezusa Chrystusa przez jawnogrzesznicę ( Łk 7,37; J 12,3; Mt 26,7; Mk 14,3), Klemens stwierdza, że „namaszczonymi stopami Pana są apostołowie"47. Dalej wyjaśnia, że przez apostołów Chrystus dalej glosil kerygmat: tam, gdzie przybyły Jego stopy, tj. apostołowie, przez których On sam przepowiadał Ewangelię, aż po krańce

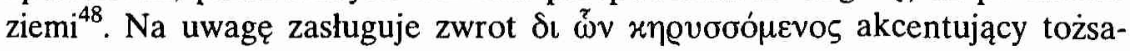

${ }^{40}$ Tamże I 88, 3; 81, 1, GCS 12, 142 i 137; por. Brontesi, dz. cyt., s. 216, 227, 230, 336, 353, 467; Völker, dz. cyt., s. 120.

41 Tamże I 90, 1, GCS 12, 142; por. Brontesi, dz. cyt., s. 216, 222.

42 Tamże I 80, 2; 92, 1, GCS 12, 137 i 144; por. Völker, dz. cyt., s. 175.

${ }^{43}$ Tamże I 76, 1, GCS $12,134$.

${ }^{44}$ Por. Stromata VI 58, 1; VII 7, 4; zob. Brontesi, dz. cyt., s. 382; Völker, dz. cyt., s. 94, 324.

45 Por. tamże VI $45,4$.

${ }^{46}$ Por. tamże II 44, 1; VI 45, 4; zob. Völker, dz. cyt., s. 594.

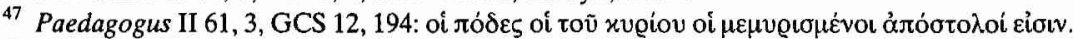

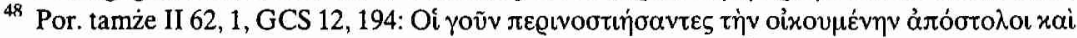

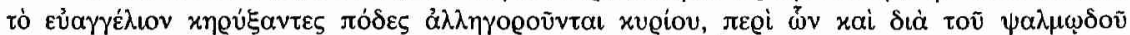

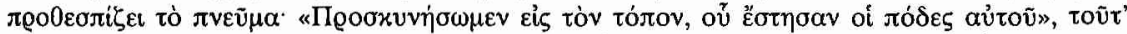

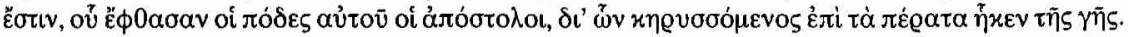


mość misji apostołów z misją Chrystusa. Ich działalność była kontynuacją misji Chrystusa sprawowaną w imieniu Chrystusa. Mając na uwadze kontekst historyczny można przypuszczać, że powyższy akcent został przez Klemensa zamieszczony celowo. Najprawdopodobniej w sytuacji mnożących się herezji w Kościele aleksandryjskim ${ }^{49}$ chodzilo o podkreślenie absolutnej ortodoksyjności kerygniatu Dobrej Nowiny.

Specyficzna funkcja przygotowawcza, w tym dziele, przypadła Janowi

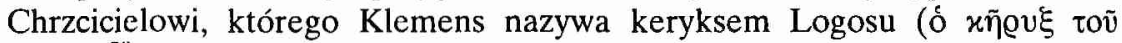
$\lambda$ ó $\gamma o v)^{50}$. Nawiązując do słów Jana Chrzciciela "Prostujcie drogę Pańską" (J 1,23; Iz 40,3) Klemens stwierdza:

„Jan jest poprzednikiem, i jego głos jest poprzednikiem Słowa, jest glosem zachęty, który przygotowuje do zbawienia i zaprasza do niebieskiego dziedzictwa" ${ }^{\text {"51. }}$.

Charakteryzując działalność misyjną apostołów Klemens zwraca uwagę nie tylko na ich funkcję głosicieli (heroldów), lecz również zaznacza, że ich zadaniem było ukazanie mocy Słowa Bożego poprzez nauczanie. Klemens stwier-

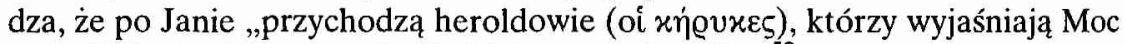

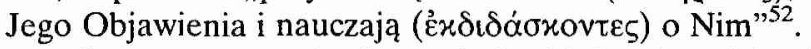

Klemens ponownie akcentuje boski charakter ich misji, w której apostołowie pełnią poniekąd rolę narzędzia Bożego. Ich przepowiadanie posiada coś $\mathrm{z}$ autorytetu boskiego i proroczego. Mając na uwadze wzniosłość i powagę tej funkcji Klemens stwierdza:

„Ale czy mógłby ktoś nie zadrżeć przed prorokami Boga Wszechwładnego, przed

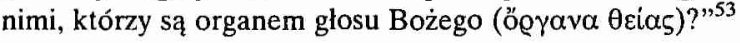

${ }^{49}$ Por. F. Drączkowski, Niektóre tendencje i zasady pierwszych wspólnot heterodoksyjnych na podstawie „Stromatów” Klemensa Aleksandryjskiego, RTK 23 (1976) z. 4, 55-84.

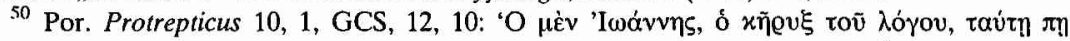

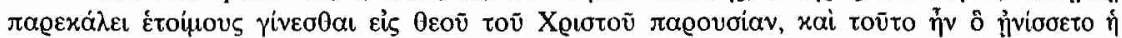

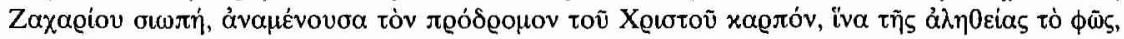

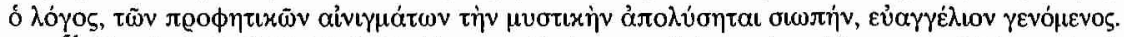

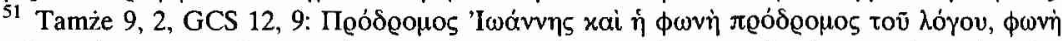

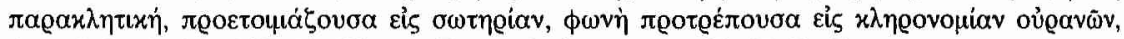
thum. Solowianiuk, PSP 44, 123; por. Brontesi, dz. cyt., s. 4, 27, 37, 41-43.

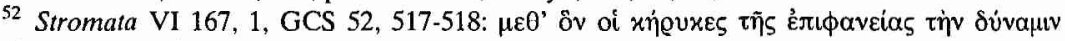

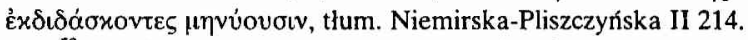

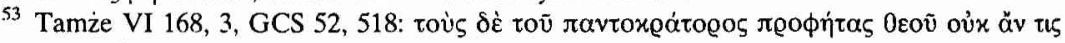

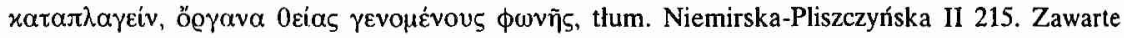

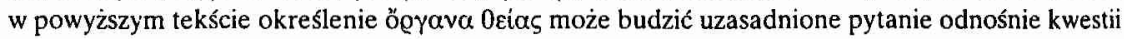
Bożego natchnienia w przepowiadaniu apostołów. Należałoby zbadać inne analogiczne wypowiedzi Klemensa, które - być może - dałyby odpowiedź na pytanie: czy Klemens widzi czysto nadrzędną rolę apostołów, których glos należy utożsamić z głosem Boga, czy też pojmuje natchnienie w sensie rozumianym przez dzisiejszych egzegetów?, por. Völker, dz. cyt., s. 354, 355. 
Keryksem Dobrej Nowiny nazywa również Klemens św. Pawla akcentując jego

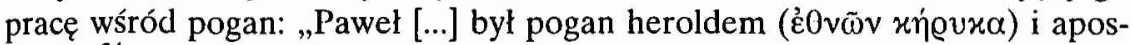
tolem" 54 .

Mając na uwadze zakres funkcji kerygmatycznej apostołów Klemens akcentuje jej wymiar uniwersalny - zarówno geograficzny jak i historyczny:

„Apostołowie na wzór Pana głosili Ewangelię również pozostającym w Otchłani" ${ }^{55}$; „Apostołowie i nauczyciele, którzy obwieszczali imię Syna Bożego za życia, obwieszczali je dalej nawet już po śmierci, dzięki swej mocy i wierze, tym, którzy przed nimi pomarli"

4. Święci, przyjaciele Boga (gnostycy) w funkcji keryksów. Ogólną charakterystykę człowieka doskonałego (gnostyka) znajdujemy w następującej wypowiedzi Klemensa:

„Nasz gnostyk jest więc jedynym człowiekiem, który do późnego wieku trwa w badaniu współczesnych Pism Kościoła oraz kontynuuje ścisłą wierność (por. 2 Tm 2,15) apostolskiego i kościelnego wykładu zasad wiary oraz żyje jak najściślej według Ewangelii, doznając natchnienia od Pana, aby mógl znaleźć, począwszy od Pana i proroków, argumenty, których szuka. Życie bowiem gnostyka jest, jak sądzę, niczym innym jak działaniem i słowem, zgodnym z przekazem Pana"57.

W powyższej wypowiedzi Klemens określa zwięźle podstawowe zadania gnostyka w trzech punktach:

a) badanie pism;

b) nauczanie zgodne z nauką apostołów i Kościoła. W tym miejscu Klemens odwołuje się do wypowiedzi św. Pawła: „Dołóz starania, byś sam stanął przed Bogiem jako godny uznania pracownik, który nie przynosi wstydu, trzyma się

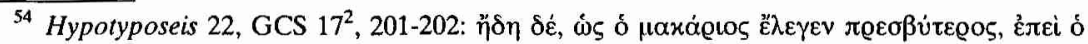

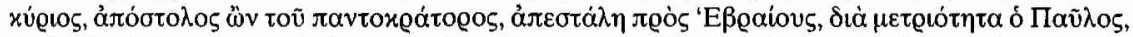

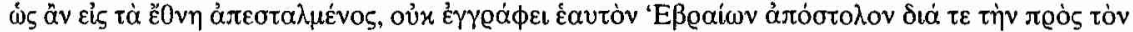

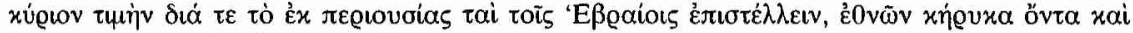

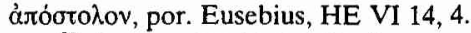

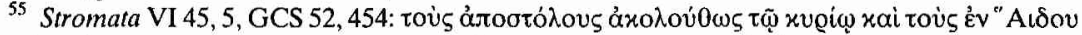

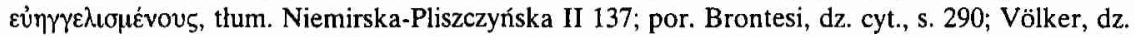
cyt., s. 594.

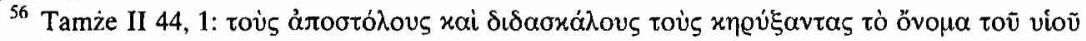

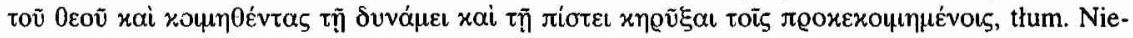
mirska-Pliszczyńska I 159; por. Völker, dz. cyt., s. 594.

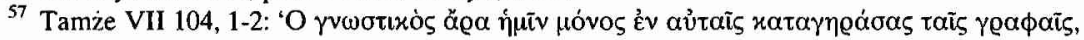

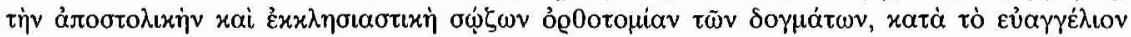

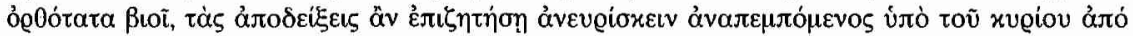

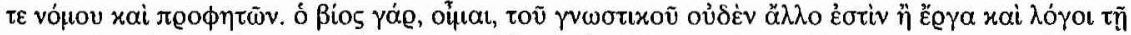

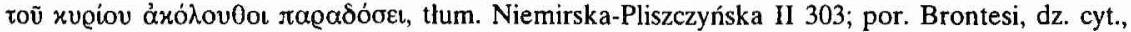
s. 568; Völker, dz. cyt., s. 446, 451-452, 498. 


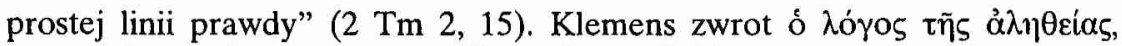

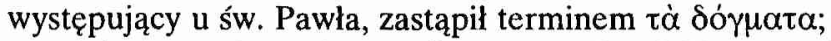

c) życie zgodne $z$ Ewangelią. Następnie - jakby w podsumowaniu - stwierdza krótko: „Życie bowiem gnostyka jest, jak sądzę, niczym innym jak działaniem i słowem, zgodnym z przekazem Pana". Klemens posługuje się tu dwoma

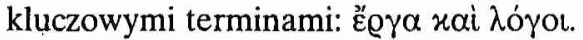

Warto zauważyć na kanwie tych wyrażeń, że istotą kerygmatu jest ewangelizacja dokonująca się przez propagowanie słowa Bożego oraz przykład zgodnego $\mathrm{z}$ nim postępowania; ten podwójny wymiar kerygmatu podkreślał Bazyli Wielki twierdząc, że jego ,pełna realizacja dokonuje się przez czyn

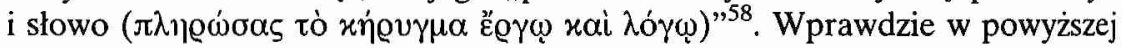
wypowiedzi Klemens nie formułuje tak wyraźnie istoty kerygmatu, jednak w wielu swoich wypowiedziach akcentuje, że życie zgodne z Ewangelią ma wartość świadectwa ${ }^{59}$, które pełni funkcję ewangelizacyjną ${ }^{60}$.

$\mathrm{Na}$ kanwie tego, co wyżej zostało powiedziane, E. Hofmann ${ }^{61}$ stwierdza $\mathrm{z}$ pewnym zdziwieniem, że Klemens mówiąc o biskupach nigdzie nie wspomina, że ich zadaniem jest przekaz nauki wiary, czyli kerygmatu. Wspomniany autor zaznacza, że wprawdzie Klemens mówi o Kościele założonym przez apostołów oraz o biskupach, którzy zostali ustanowieni przez apostołów ${ }^{62}$ przełożonymi poszczególnych wspólnot, milczy jednak na temat ich funkcji nauczycielskiej. Co więcej, funkcję nauczania, czyli przekazu doktryny wiary, przyznaje gnostykom. Aby ten dylemat rozwiązać należy najpierw wyjaśnić kilka podstawowych założeń, dotyczących rozumienia istoty Kościoła przez Klemensa Aleksandryjskiego oraz roli "prawdziwych gnostyków” ${ }^{\text {"33 }}$ w życiu Kościoła.

W przekazach popularnych dość często blędnie utożsamia się gnostyków $\mathrm{z}$ przedstawicielami herezji oraz gnozę $\mathrm{z}$ herezją ${ }^{64}$. Należy wyjaśnić, że w pi-

${ }^{58}$ De baptismo 5, 31; PG 31, 1625 A; por. F. Drączkowski, Kerygmat, EK VIII 1362.

${ }^{59}$ Por. P. Szczur, Oblicza mitości. „Mitość daje się poznać w sposób wieloraki”. Cnoty po-

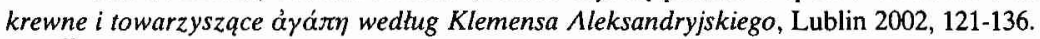

${ }^{60}$ Por. Stromata VII 54, 1; VI 106, 2; zob. Brontesi, dz. cyt., s. 453; Völker, dz. cyt., s. 454, 457, 523.

${ }^{61}$ Die Kirche bei Clemens von Alexandrien, w: Vitae et Veritati. Festgabe für Karl Adam, Düsseldorf 1956, 15.

${ }^{62}$ Por. Stromata IV 75, 1; Quis dives salvetur 42, 2. 8; zob. Brontesi, dz. cyt., s. 535; Völker, dz. cyt., s. 451, 571; P. Szczur, Urzqd biskupa, s. 64.

${ }_{63}$ Por. E. Gilson - P. Böhner, Historia filozofii chrześcijańskiej. Od Justyna do Mikolaja Kuzańczyka, tłum. S. Stomma, Warszawa 1962, 43: „Według Klemensa nie każdy chrześcijanin jest gnostykiem, gdyż nie u każdego wiara osiąga doskonałośc. Ale każdy gnostyk godzien tego imienia, musi być chrześcijaninem, gdyż prawdziwa gnoza jest doskonałą wiarą".

${ }^{64} \mathrm{O}$ trudnościach związanych z zawiłą terminologią Klemensa pisali m.in. E. de Faye, Clément d'Alexandrie. Étude sur les rapports du christianisme et de la philosophie au IT siècle, Paris 1906, 287; Völker, dz. cyt., s. 309, 313, 316. Niektórzy posługując się terminami: „gnoza”, „gnostyk", nie uwzględniają różnicy występującej między gnozą ortodoksyjną i heretycką. Na temat definicji gnostycyzmu zob. W. Myszor, Gnostycyzm - przegląd publikacji, STV 9 (1971) nr 1, 
smach Klemensa określenie „gnostyk” znajduje wiele ekwiwalentnych substytutów. Gnostycy są „mężami dojrzałymi w miłości do Boga",65, „mężami w pełni

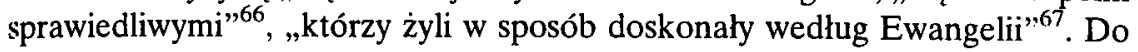

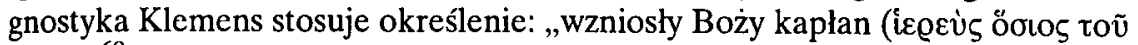
$\theta \varepsilon o \tilde{u}) " 68$. Siódmy Stromat Klemensa poświęcony jest charakterystyce doskonałego chrześcijanina, czyli gnostyka, który trwa nieustannie na modlitwie ${ }^{69}$. Krótko mówiąc, gnostyk jest tym, który „doszedl do wyjątkowo wysokiego stopnia świętości” ". Do gnostyka Klemens stosuje określenie: „przyjaciel Boga”, nawiązując do słów Chrystusa wypowiedzianych podczas Ostatniej Wieczerzy, który swymi przyjaciółmi nazwał apostołów (zob. J 15,15). Według Klemensa apostołowie byli prawdziwymi gnostykami ${ }^{71}$. Mając więc na uwadze pewną dewaluację, której ulegl termin "gnostyk” we współczesnym języku, zamiast słowa "gnostyk" należałoby stosować terminy: „święty”, „przyjaciel Boga”, „doskonały w miłości”, „w pełni doskonały”, „,doskonały chrześcijanin”.

Mając na uwadze naukę o Kościele należy również wyjaśnić, że dla Kle-

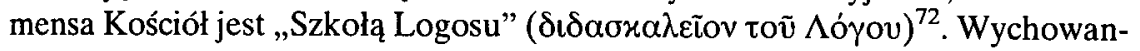
kowie tej szkoły, czyli Lud Boży, dzielą się na trzy grupy: przyjaciół ( $\phi i \lambda o \iota)$,

369-402. Terminy te u Klemensa w zasadzie używane są w pozytywnym znaczeniu, chociaż znajdujemy też dowody świadczące o ich dewaluacji (zob. Stromata II 52, 5). Klemens Aleksandryjski posługuje się terminem gnwstikj na oznaczenie ideału świętości chrześcijańskiej [por. Völker, dz. cyt., s. 507-609; paragraf 3 rozdziału V (Das tätige Leben) zatytulowany Das Porträt des Gnostikers], zaś wyrazem $\gamma$ vōoı - na określenie pełni i zrozumienia wiedzy dotyczącej nauki chrzescijańskiej [por. J. Moingt, La gnose de Clément d'Alexandrie dans ses rapports avec la Foi et la Philosophie, RSR 37 (1950) 219-226: "La gnose comme développement de la foi”]. W czasach dzisiejszych historycy i filolodzy dosyć często jeszcze posługują się terminami: „gnoza" i ,gnostyk”, w znaczeniu: ,herezja” $\mathrm{i}$,heretyk". $\mathrm{Z}$ drugiej strony jednak pojawiają się liczne prace na temat gnozy ortodoksyjnej np.: J. Dupont, Gnosis. La connaissance religieuse dans les Epîtres de saint Paul, Louvain 1949; K. Prümm, Gnosis an der Wurzel des Christentums?, Salzburg 1972; R. Wilson, Gnosis and the New Testament, Oxford 1968.

${ }^{65}$ Stromata VII 67,2 , GCS $17^{2}, 48$, thum. Niemirska-Pliszczyńska II 271; por. Völker, dz. cyt., s. 567.

66 Tamże VI 107, 2, GCS 52, 485, tłum. Niemirska-Pliszczyńska II 176; por. Brontesi, dz. cyt., s. 273; Völker, dz. cyt., s. 524, 586, 601.

${ }^{67}$ Tamże VI 106, 1, GCS 52, 485, tłum. Niemirska-Pliszczyńska II 175; por. Völker, dz. cyt., s. $498,523$.

${ }^{68}$ Tamże VII 36, 2, GCS $17^{2}, 28$, tłum. Niemirska-Pliszczyńska II 246; por. Brontesi, dz. cyt., s. 9, 141, 192, 200; Völker, dz. cyt., s. 510 .

${ }^{69}$ Por. tamże VII $35,1-47,1$.

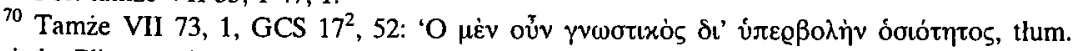
Niemirska-Pliszczyńska II 276; por. Brontesi, dz. cyt., s. 421-422, 474; Völker, dz. cyt., s. 415, 420.

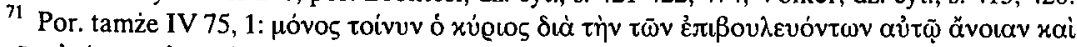

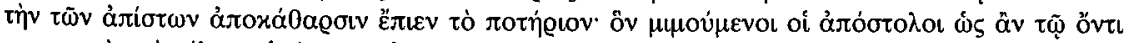

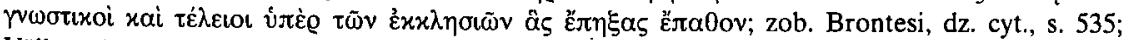
Völker, dz. cyt., s. 451, 571.

${ }^{72}$ Por. Paedagogus III 98, 1, GCS 12, 289; zob. Völker, dz. cyt., s. 155; F. Drączkowski, Kościót jako szkoła Logosu w doktrynie Klemensa Aleksandryjskiego, RTK 28 (1981) z. 4, 137-143. 


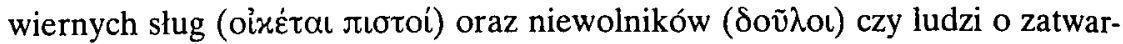

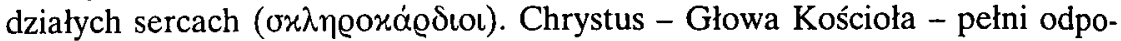
wiednie funkcje wobec każdej z tych grup: dla przyjaciół jest Nauczycielem

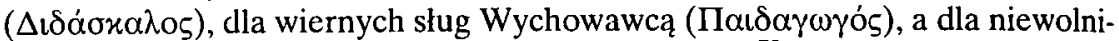
ków grzechu, czyli chorych, jest Lekarzem ('I $\alpha \tau \varrho o ́ \varsigma){ }^{73}$.

Kiedy Klemens pisze, że „tylko w prawdziwym i starym Kościele można znaleźć gnozę" ${ }^{, 74}$, ma na myśli gnostyków, którym została powierzona opieka nad depozytem doktryny wiary i obyczajów. Pozycja gnostyków w Kościele szkole Logosu, według Klemensa, jest szczególna $z$ racji tego, że są „mężami

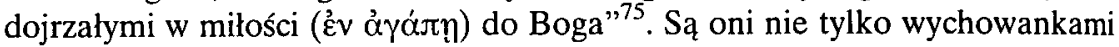
szkoły Logosu, ale również uczestniczą w jakimś stopniu - jako upodobnieni do Chrystusa i z Nim ściśle zjednoczeni i jednomyślni - w Jego działalności „leczniczej, wychowawczej i nauczycielskiej”. Ważna na ten temat jest następująca wypowiedź Klemensa:

„A spośród wybranych, powiada [tj. św. Jan w Apokalipsie], są jeszcze bardziej wybrani (por. Ap 4,4$)^{76}$, ci mianowicie, którzy zgodnie ze swoją doskonalą gnozą

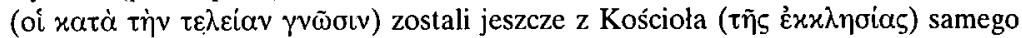
wybrani jak kwiaty, i zaszczyceni wspaniałą czcią, jako sędziowie i zarządcy, zarówno spośród Judejczyków jak Hellenów, tych dwudziestu czterech, przy dwakroć powiększonej ilości błogosławionych, gdyż istniejące tu na ziemi w Kościele

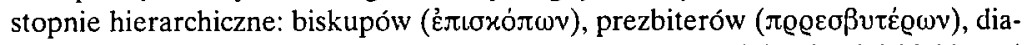

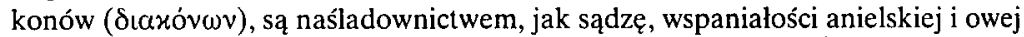
ekonomii zbawienia, której mogą oczekiwać, wedle słów Pisma Świętego, ludzie, których życie upłynęło w pełni sprawiedliwości, zgodnie z Ewangelią, wedle śladu stóp apostolskich"77.

Tekst powyższy należy do najczęściej cytowanych wypowiedzi Ojców Kościoła jako świadectwo istnienia w Kościele w czasach Klemensa stopni hierarchicznych: biskupa, prezbitera i diakona ${ }^{78}$. Nie to jednak nas w tej chwili interesuje.

${ }^{73}$ Por. F. Drączkowski, Kościót - Agape wedtug Klemensa Aleksandryjskiego, Lublin 1983, 136-158.

${ }^{74}$ Stromata VII $92,3, \mathrm{GCS} 17^{2}, 65$.

75 Tamże VII 67, 2, GCS $17^{2}, 48$, tlum. Niemirska-Pliszczyńska II 271; por. Völker, dz. cyt., s. 567.

76 Por. Quis dives salvetur 36, 1, zob. Völker, dz. cyt., s. 407, 508, 524.

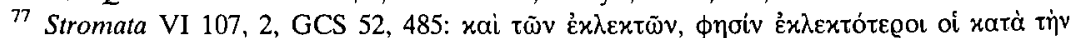

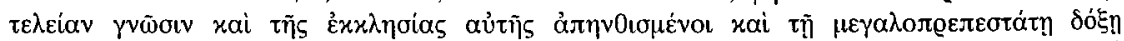

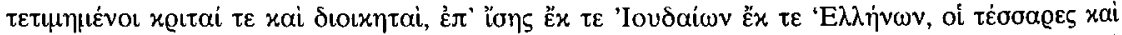

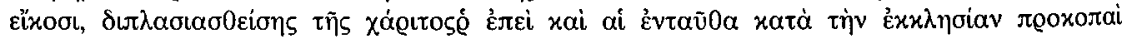

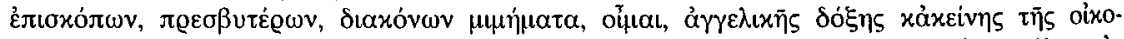

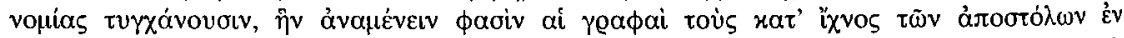

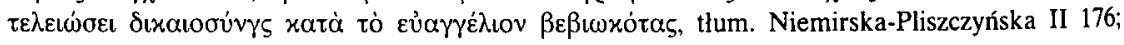
por. Brontesi, dz. cyt., s. 273; Völker, dz. cyt., s. 524, 586, 601 .

${ }^{78}$ Por. Brontesi, dz. cyt., s. 554; Hofmann, dz. cyt., s. 16; Völker, dz. cyt., s. 157; J. Quasten, Patrologia (przekład włoski), II, Torino 1871, 305; G. Bardy, La théologie de l'Eglise de saint Irénée au concile de Nicée, Paris 1947, 116; Szczur, Urzqd biskupa, s. 65-67. 
Ważne jest, że w organizacji szkoły Logosu do funkcji specjalnych zostają wybrani ci, którzy posiadają doskonałą gnozę ( tycy. Z grupy gnostyków rekrutują się, lub powinni się rekrutować, ci, którzy w Kościele są sędziami, zarządcami, biskupami, prezbiterami i diakonami. Zdaniem Klemensa, apostołowie byli prawdziwymi gnostykami ${ }^{79}$. Po śmierci apostołów ich działanie i funkcje przejmują inni. Klemens nie zamyka grona apostołów do liczby dwunastu. Jego zdaniem ,,jeszcze i teraz (xai vṽv) mogą

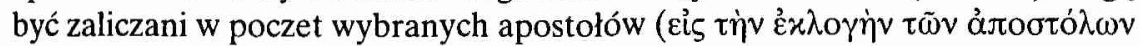

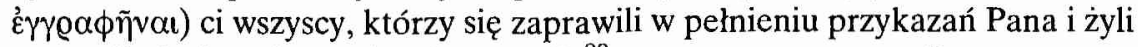
w sposób doskonały według Ewangelii" ${ }^{80}$, to znaczy gnostycy. Grono apostołów, w koncepcji Klemensa, rozciąga się niejako w kategorii czasu aż do współczesności. Apostołowie byli gnostykami. Współcześni gnostycy są następcami gnostyków - apostołów, bo dalej pełnią w Kościele te funkcje, które pelnili apostołowie. Na barkach tej grupy spoczywa odpowiedzialność za wzrost Ciała Chrystusowego.

Zaszczycenie niektórych z nich godnością biskupa, prezbitera czy diakona nie zmienia postaci rzeczy. Doskonała ỏyó $\Uparrow \eta$ każe „trwożyć im się o braci, dla nich popełniać mądre szaleństwa" ${ }^{\text {81 }}$. Zdaniem Klemensa:

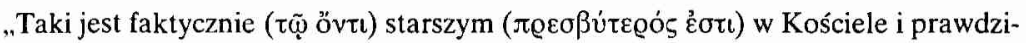
wym sługą (diakonem) woli Bożej, jeśli sam pełni i wykłada przykazania Boże. I nie dlatego uważany jest za sprawiedliwego, że przez ludzi zostal wybrany ( $\alpha \dot{v} \theta \varrho \omega \dot{\jmath} \pi \omega v$

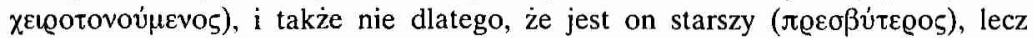

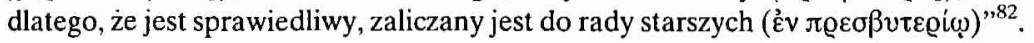

Niekoniecznie wypowiedź powyższa wskazywać musi, jak to chce F. Hofmann, na jakąś opozycję Klemensa wobec współczesnej mu hierarchii kościelnej. Hofmann ${ }^{83}$ niepotrzebnie przeciwstawia gnostyka biskupowi. Intencją Kle-

${ }^{79}$ Por. Stromata IV 75, I, 1, GCS 52, 282, thum. Niemirska-Pliszczyńska I 338: „Z kolei

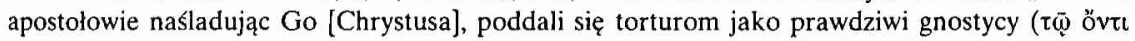
prwotıxoi) i ludzie doskonali"; zob. Brontesi, dz. cyt., s. 535; Völker, dz. cyt., s. 451, 571.

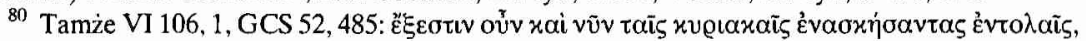

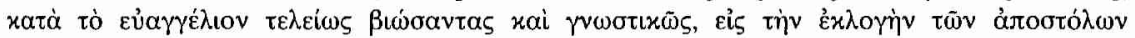

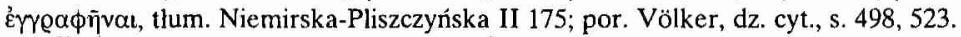

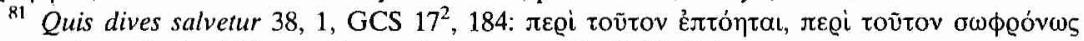

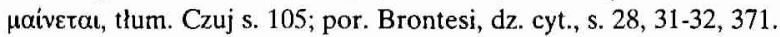

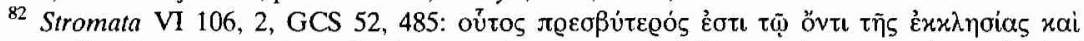

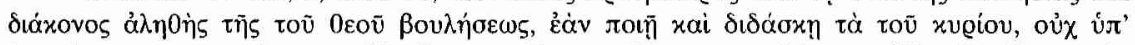

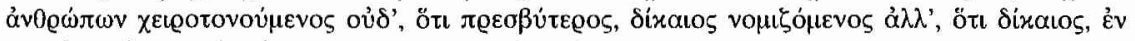

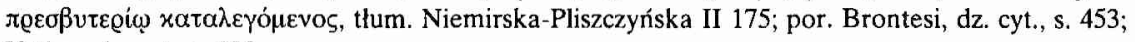
Völker, dz. cyt., s. 523.

${ }^{83}$ Por. Hofmann, dz. cyt., s. 16: „Man wird schwerlich annehmen können, dass dieses beharrliche Schweigen über das bischöfliche Lehramt nur rein zufälliger Natur ist; vielmehr legt sich der Gedanke nahe, dass Clemens die Funktion der unversehrten Weitergabe der Oberlieferung eher dem Gnostiker als dem kirchlichen Amtsträger zuerkannte". 
mensa nie było ukazanie antagonizmu między tymi osobami. Przeciwnie, wszystko, co Klemens na ten temat pisze, wskazuje na ukryty postulat, aby gnostyk byl wybierany biskupem, prezbiterem, diakonem. Nie świadczy to jeszcze o tym, że zawsze tak czyniono; $z$ drugiej strony nic nie wskazuje tez na to, ze tak nie czyniono.

O ty'm, że Klemens pragnąl dla gnostyka funkcji biskupa, prezbitera, czy diakona, wskazują inne jego wypowiedzi na ten temat, gdzie znajdujemy coś na ksztalt pocieszenia dla tych gnostyków, którzy nie doczekali się urzędu w Kościele. Klemens wskazując na Kościól niebieski, który jest według niego podobny do Kościola ziemskiego, pisze:

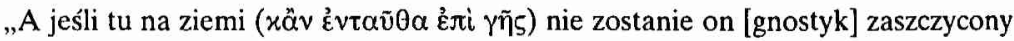

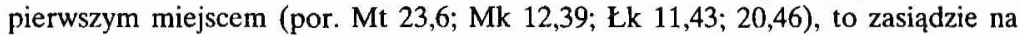
jednym $\mathrm{z}$ dwudziestu czterech tronów i będzie sądzil lud, jak mówi Jan w Apokalipsie (por. Ap 4, 4) ${ }^{84}$. [...]. „O nich [gnostykach] pisze Apostoł, że ci, uniesieni «na obłokach» (por. 1 Tes 4, 17), będą najpierw diakonami, z kolei zaliczeni zostaną do rady prezbiterów, $[\ldots]$ aż urosną do «ideału człowieka w pełni doskonałego» (por. Ef 4,13$)^{* 185}$.
\end{abstract}

Klemens wyróżnia dwie hierarchie - hierarchię doskonałości i hierarchię urzędu. Zakresy obu tych hierarchii mogły, ale nie musiały się pokrywać. Dlaczego Klemens stawiał w Kościele na hierarchię doskonałości? Dlatego, wydaje się, że jej zakres jest o wiele szerszy niż tej drugiej. $Z$ grona gnostyków tylko niektórzy otrzymali urzędy w Kościele. Pozostała reszta stanowić miała w Kościele ,zdrowy zaczyn”, „elitę laikatu” - żeby wyrazić się adekwatnie do terminologii Vaticanum Secundum. Przerzucenie ciężaru odpowiedzialności za Kościół wyłącznie na barki hierarchów znacznie by Kościół osłabiło. Jeśli Klemens mówi o odpowiedzialności gnostyków za Kościół, to domyślnie mówi o gnostykach biskupach, prezbiterach i diakonach oraz o gnostykach nie wchodzących w skład hierarchii. Zakres terminu „gnostycy” jest o wiele szerszy niż zakres określenia „hierarchia kościelna”.

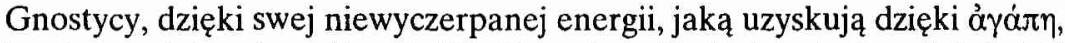

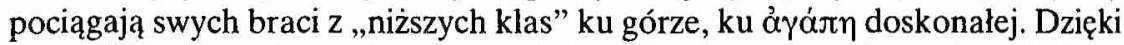
dojrzałej àyá $\rceil \eta$ osiągają heroizm cnót, budując swym przykładem innych. Jako gnostycy są ipso facto „świadkami” prawdy Chrystusowej, gotowi w każdej chwili świadectwo to pieczętować krwią. W tym zakresie gnostycy idą w ślady

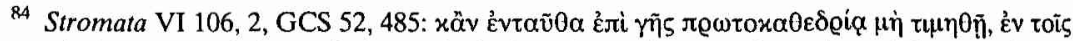

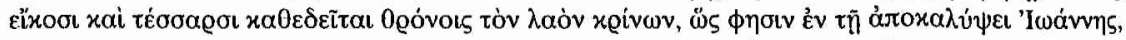
thum. Niemirska-Pliszczyńska II 175; por. Brontesi, dz. cyt., s. 453; Völker, dz. cyt., s. 523.

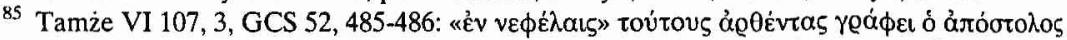

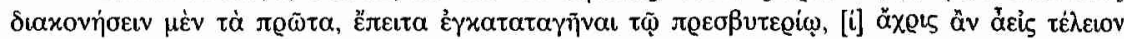

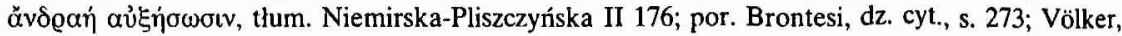
dz. cyt., s. 505,524 . 
Chrystusa i apostołów. Zdaniem Klemensa, istnieje pewien ,ciąg od góry”, od Chrystusa Lekarza, Wychowawcy i Nauczyciela, który dla dobra swej szkoly (Kościoła) oddal swe życie, poprzez apostołów i gnostyków:
„Pierwszy więc Pan wypił kielich (por. Mt 20,22; 26,29) z powodu głupoty tych, którzy Go zdradzili, i dla oczyszczenia niewierzących. Z kolei apostołowie naśla- dując Go poddali się torturom, jako prawdziwi gnostycy i ludzie doskonali, dla

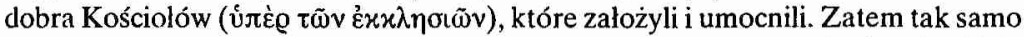 i gnostycy, idąc w ślad apostolów, winni zachowywać stan bez grzechu i z miłości do Pana milować bliźniego, aby, jeśli wezwie ich do tego sytuacja zewnętrzna, potra-

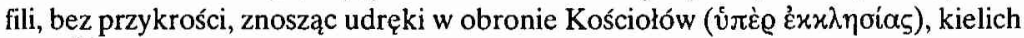 wypic $^{86}$.

„Świadectwo" gnostyka, przepełnionego miłością do Pana, ma szereg funkcji, o których już wcześniej była mowa. Do poprzednich dochodzi staranie o calą społeczność szkolną, przynależną do szkoły Logosu. Deklaracja ảyájๆ doskonałej, podpisana krwią męczeńską, ma również „umocnić członków Kościoła"87. Gnostyk oddaje się na tortury po to, aby „,doznali umocnienia członkowie Kościoła”88. Najogólniej mówiąc grupa wychowanków trzeciego oddziału,

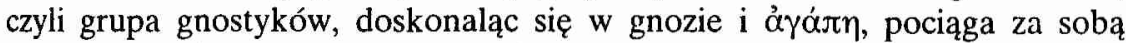
innych i w ten sposób uczestniczy aktywnie w miłości Chrystusa do Kościola. Gnostycy niejako utożsamiają się z Logosem, kontynuują Jego działalność leczniczą, wychowawczą i nauczycielską.

Boski Logos - Jezus Chrystus, który działa w swym Kościele, przez swych przyjaciół prowadzi swój lud do świętości, która staje się bramą życia wiecznego. Stąd Klemens określa lud Boży jako „lud święty”, , „lud zbawiony”, a Kościól nazywa syntetycznie jednym terminem - „zbawienie”:

„Jak wola Boża jest dziełem, które nazywamy światem, tak Jego pragnienie jest zbawieniem ludzi i nazywa się Kościołem ${ }^{91}$ [...]. Zbawienie więc, to pójście za Chrystusem" ${ }^{\text {.92 }}$.

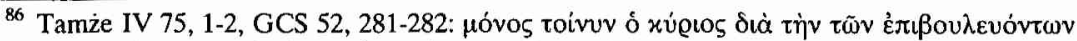

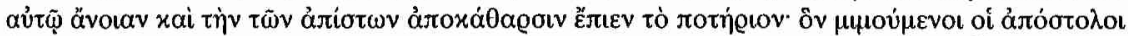

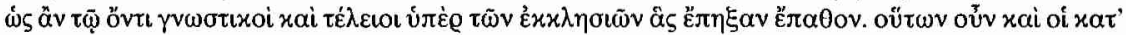

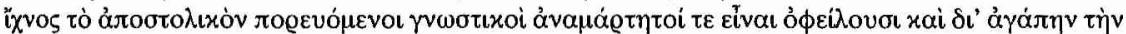

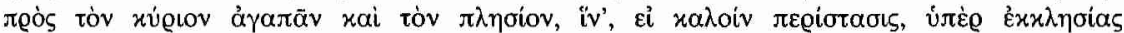

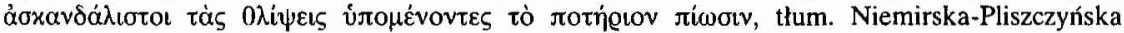
I 338; por. Brontesi, dz. cyt., s. 535; Völker, dz. cyt., s. 587, 594.

${ }_{87}^{87}$ Tamże IV 85, 1, GCS 52, 285, tłum. Niemirska-Pliszczyńska I 343; por. Brontesi, dz. cyt., s. 141, 172, 204, 501, 503, 594; Völker, dz. cyt., 561-562, 571-572.

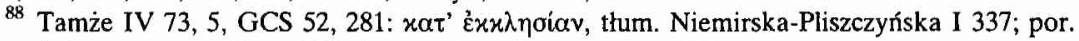
Brontesi, dz. cyt., s. 21, 23-25, 155, 534; Völker, dz. cyt., s. 571-572.

${ }^{89}$ Por. tamże VI 50, 1, GCS 52, 457.

${ }^{90}$ Por. tamże VI 42, 2, GCS 52, 452; zob. Brontesi, dz. cyt., s. 141, 168, 208-210, 27-276, 280, 288, 399, 526; Völker, dz. cyt., s. 86-87. 
Pójście za Chrystusem to życie zgodne z Ewangelią. Takie życie, samo w sobie, posiada wartość kerygmatu czynu. We wszystkich swych wypowiedziach Klemens daje zdecydowany priorytet kerygmatowi czynu. Życie doskonałe według Ewangelii posiada najwyższą wartość apostolską i ewangelizacyjną. Do tej zasady Klemens wiclokrotnie wraca akcentując, że jest ona „conditio sine qua

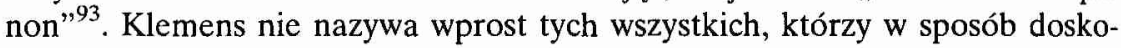
nały żyją według Ewangelii - keryksami. Jednak ci wszyscy pełnią funkcje keryksów, przyczyniając się do propagowania Ewangelii. Doskonałość i świętość jest celem wszystkich ochrzczonych, którzy w swym dążeniu do doskonałości na różny sposób „świadczą o prawdzie Ewangelii” stając się keryksami czynu. W tym aspekcie można mówić o powszechnej funkcji keryksa, która jest udziałem całego ludu Bożego. Należy zaznaczyć, że jest to funkcja wirtualna wszyscy bowiem nie osiągają natychmiast stopnia doskonalej miłości ( $\dot{\alpha} \gamma \alpha \dot{\pi} \eta \eta)$,

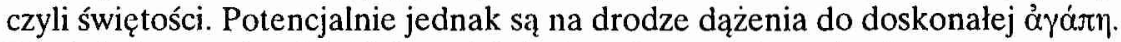
Ich świadectwo, bardziej lub mniej doskonałe, posiada walor kerygmatu.

Kerygmat słowa zastrzeżony jest dla „przyjaciół Boga”, świętych i doskonałych, którzy aktualnie „mogą być zaliczeni w poczet wybranych apostołów"94. Ich posluga słowa może dokonywać się w dwojakiej formie: bądź przez kerygmat pisemny, bądź ustny. Klemens stawiając akcent na hierarchię doskonałości, a nie na hierarchię urzędu, miał na uwadze powszechność kerygmatu słowa. Każdy bowiem, niezależnie od funkcji hierarchicznej w Kościele, jeśli tylko dorósl do miary doskonałości przyjaciół Chrystusa, mógł realizować posługę słowa w formie przez siebie wybranej. Każdy winien posługiwać się „zgodnie ze swym uzdolnieniem naturalnym"95. Mając na uwadze obydwa rodzaje kerygmatu, tj. kerygmat słowa i kerygmat czynu, można mówić o jego powszechnym wymiarze. „Jeden wykazuje się czynem, drugi - słowem, które toruje drogę szlachetnemu dzialaniu oraz prowadzi słuchaczy do dobrych czynów. Zbawiać może slowo, zbawiać może czyn"96.

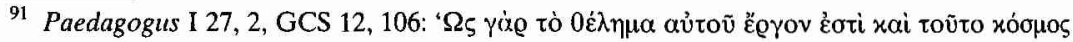

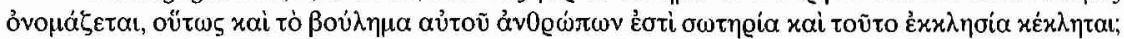
por. Brontesi, dz. cyt., s. 13-14, 53, 140, 167, 200, 254, 257, 305-308, 365, 388, 397, 399, 490, 522; Völker, dz. cyt., s. 154, 228.

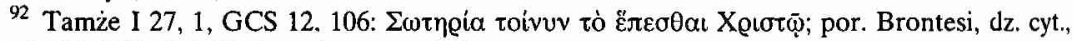
s. 10, 13-14, 257, 424; Völker, dz. cyt., s. 588.

${ }_{93}$ Por. Stromata I 46, 4; IV 111, 1; 72, 1-2; VI 105, 1-106, 4; VII 72, 1; 84, 1.

94 Tamże VI 106, 1, GCS 52, 485, tłum. Niemirska-Pliszczyńska II 175; por. Völker, dz. cyt., s. $498,523$.

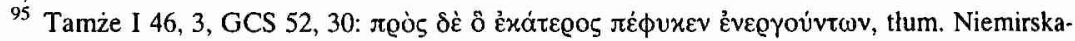
Pliszczyńska I 35; por. Plato, Respublica IV 423 D; Völker, dz. cyt., s. 5.

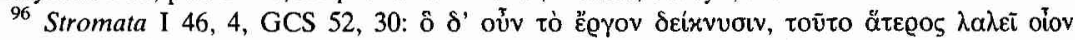

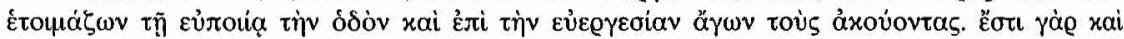

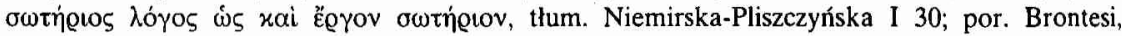
dz. cyt., s. 4, 216, 223, 225, 230, 550 . 


\section{UNIVERSALITY OF THE ROLE OF KERYKS \\ IN THE ANCIENT CHURCH. \\ THE ATTITUDE OF CLEMENS OF ALEXANDRIA}

(Summary)

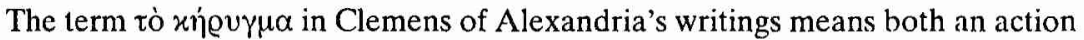
performed in time and the contents, substance, subject of the Good News the contents of the Gospel. The conveyor of the kerygmat is a word, which can be said or written. On the basis of this assumption Clemens talks about two kinds of kerygniat - oral and written. In the times of persecution the written transmission accomplished the principle of kerygmat universality in a fuller way, as it reached all environments, also the circles that were unfavourable or hostile towards Christianity. God's Word- the Secular (Eternal) Wisdom - is the only source and giver of . the kerygmat. By the will of Jesus Christ, the Apostles became the continuators of His mission, preaching the Gospel to the whole of creation, also to those who remained in Limbo. The continuators of the apostolic mission are the friends of Christ - Gnostics, who evangelize both through their exemplary life and through the word. Clemens does not limit evangelization to the group or persons included in the Church hierarchy, i.e. bishops, priests and deacons. However, he postulates that the representatives of the hierarchy should be chosen from among the circle of Gnostics. In this way he extends the circle of keryks distinguishing themselves by the perfection of their lives, as well as representatives of the laity. Ali the christened were summoned to sanctity. Therefore, theoretically, any Christian could become a keryks of the Good News, if only they could accomplish in their lives the ideal of a man mature in love. Thus, in theory, the function of a keryks became fully universal. However, life practice did not always confirm this assumption. 